\title{
Elisabeth Wishnick, Mending Fences, The Evolution of Moscow's China Policy from Brezhnev to Yeltsin
}

University of Washington Press, Seattle, 2001, 306 pp.

\section{Valérie Niquet}

\section{OpenEdition}

\section{Journals}

Édition électronique

URL : http://journals.openedition.org/chinaperspectives/654

DOI : $10.4000 /$ chinaperspectives. 654

ISSN : 1996-4617

\section{Éditeur}

Centre d'étude français sur la Chine contemporaine

Édition imprimée

Date de publication : 1 octobre 2003

ISSN : 2070-3449

\section{Référence électronique}

Valérie Niquet, «Elisabeth Wishnick, Mending Fences, The Evolution of Moscow's China Policy from Brezhnev to Yeltsin », China Perspectives [En ligne], 49 | september-october 2003, mis en ligne le 17 janvier 2007, consulté le 22 septembre 2020. URL : http://journals.openedition.org/chinaperspectives/ 654 ; DOI : https://doi.org/10.4000/chinaperspectives.654

Ce document a été généré automatiquement le 22 septembre 2020

(c) All rights reserved 


\section{Elisabeth Wishnick, Mending Fences, The Evolution of Moscow's China Policy from Brezhnev to Yeltsin}

University of Washington Press, Seattle, 2001, 306 pp.

Valérie Niquet

\section{NOTE DE L'ÉDITEUR}

Translated from the French original by Nick Oates

1 In contrast to numerous Western countries, the Soviets and their successors harbour few illusions about China, as demonstrated in one of the principal revelations of this work. That does not mean, however, that Soviet, then Russian, policy towards China has always been impressed with the seal of efficacy.

2 As the title indicates, the work by Elisabeth Wishnick tackles the question of the relations between Moscow and Peking from the point of view of the former capital; it thus fills an important lacuna. Dealing with a period of thirty years that is rich in exciting new developments (1969-1999), this book is very factual and descriptive. But it also proves to be extremely useful for the historical study of the decision-making process in the USSR - which appears a great deal more complex now than it ever could have done at the time-, as well as of the multiple strands of evolutionary factors-internal and external, institutional and economic, central and regional. These retrospective discoveries can, in their turn, furnish us with some tracks for an analysis of the processes underway in China today.

3 The chapter dedicated to the rivalries of influence between Ustinov, then minister of defence, Suslov, the party ideologue, Gromyko, the foreign minister, and Andropov, the man from the KGB, the best informed and, like Putin today, the most pragmatic, is 
particularly interesting in this respect. It is, moreover, Andropov who was to rapidly extend the process of rapprochement with China that was begun by Brezhnev in Tashkent in March 1982.

4 The work also reveals how the superimposition of diverse interests can produce a long paralysis until a man who possesses the means and the will to break the yoke comes to power. In the Soviet case, that man was Mikhail Gorbachev. But the difference between the USSR and China derives from the fact that, even today, the latter has been able, thanks to the reforms initiated by Deng Xiaoping, to escape the economic and strategic urgency which confronted the former in the 1980s.

5 The interest of the work lies equally in the use of new sources, central and regional archives of the Party that have been published recently, documents of the KGB and of the Soviet ministry of foreign affairs. On the other hand, it would have been good to see the border question dealt with in more depth and from a clearer historical perspective, in particular with regard to the frontiers that the Soviet Union and China shared in Central Asia before 1992. One last regret: this work stops at the Yeltsin era. It thus remains to be hoped that Elisabeth Wishnick will next deliver us a second volume dealing with the present-day period, which in retrospect could well give the Yeltsin era and its excesses -including their pro-Chinese components- the appearance of a parenthesis. ${ }^{1}$

\section{NOTES}

1. The article by Elisabeth Wishnick on «Les relations sino-russes dans le nouveau contexte international», Perspectives chinoises, ํํ. 72, July-August 2002, pp. 4-18, already offers a fruitful read, however. 